Synthesis, part of a Special Feature on The Energy-Water Nexus

\title{
The Energy-Water Nexus in Texas
}

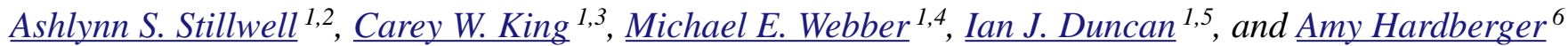

\begin{abstract}
Understanding the nexus between energy and water - water used for energy and energy used for water - has become increasing important in a changing world. As growing populations demand more energy supplies and water resources, research aims to analyze the interconnectedness of these two resources. Our study sought to quantify the energy-water relationship in Texas, specifically the relationship between electricity generation and water resources as it pertains to policy and society. We examined the water requirements for various types of electricity generating facilities, for typical systems both nationwide and in Texas. We also addressed the energy requirements of water supply and wastewater treatment systems, comparing national averages with Texas-specific values. Analysis of available data for Texas reveals that approximately 595,000 megaliters of water annually - enough water for over three million people for a year - are consumed by cooling the state's thermoelectric power plants while generating approximately 400 terawatt-hours of electricity. At the same time, each year Texas uses an estimated 2.1 to 2.7 terawatthours of electricity for water systems and 1.8 to 2.0 terawatt-hours for wastewater systems - enough electricity for about 100,000 people for a year. In preparing our analysis, it became clear that substantially more site-specific data are necessary for a full understanding of the nature of the energy-water nexus and the sustainability of economic growth in Texas. We recommend that Texas increase efforts to collect accurate data on the withdrawal and consumption of cooling and process water at power plants, as well as data on electricity consumption for public water supply and wastewater treatment plants and distribution systems. The overarching conclusion of our work is that increased efficiency advances the sustainable use of both energy and water. Improving water efficiency will reduce power demand, and improving energy efficiency will reduce water demand. Greater efficiency in usage of either energy or water will help stretch our finite supplies of both, as well as reduce costs to water and power consumers.
\end{abstract}

Key Words: energy; policy; Texas; water

\section{INTRODUCTION}

Energy and water are intimately interrelated: we use energy for water and we use water for energy. Despite the interconnections, historically these two sectors have been regulated and managed independently of one another. Planning for energy supply traditionally gave scant consideration to water supply issues, and planning for water supply often neglects to fully consider associated energy requirements (World Economic Forum 2009). Only recently has the energy-water nexus emerged in research and public interest (Webber 2008, Koch and Vögele 2009, Wolfe et al. 2009, Fthenakis and Kim 2010, Keller et al. 2010). Failure to consider the interdependencies of energy and water introduces vulnerabilities whereby constraints of one resource introduce constraints in the other. That is, droughts and heat waves create water constraints that can become energy constraints (Poumadere et al. 2005), and grid outages or other failures in the energy system can become constraints in the water and wastewater sectors.

Our manuscript reveals the results of analysis of the energy-water nexus in Texas by examining the water use for electricity generation and the electricity use for water and wastewater systems. We analyze this energy-water relationship in the context of its policy implications for society. Texas is a suitable geographical testbed for this analysis for a variety of reasons. First, Texas is small enough

\footnotetext{
${ }^{1}$ The University of Texas at Austin, ${ }^{2}$ Department of Civil, Architectural, and Environmental Engineering, ${ }^{3}$ Center for International Energy \& Environmental Policy, ${ }^{4}$ Department of Mechanical Engineering, ${ }^{5}$ Bureau of Economic Geology, ${ }^{6}$ Environmental Defense Fund
} 
to analyze yet is suitably large to reveal useful results that will be relevant at a national scale. Second, by producing and consuming roughly 400 billion kilowatt-hours [ $\mathrm{kWh}]$ of electricity annually, Texas is the largest generator and consumer of electricity in the United States. Third, Texas has extreme variability in water availability from the relatively water-rich eastern half of the state to the arid western half of the state. Texas is the second most populated state in the United States, and its population is predicted to double from the current 23 million to about 46 million by 2060 (Texas Water Development Board 2007). In a business-as-usual scenario (by which prior trends are projected forward into the future) that includes current power generation and announced future power plants, Texas' total electricity generation increases to nearly 490 terawatt-hours (TWh) annually by 2018 (Webber et al. 2008). Meanwhile, municipal water supply demand is predicted to grow to 10.2 million megaliters per year (ML/yr) by 2060, from a current level of about 5.6 million ML/yr (Texas Water Development Board 2007).

Droughts, heat waves, and hurricanes are common occurrences in Texas, and because of the energywater nexus, they introduce a coupled cross-sectoral vulnerability. These vulnerabilities might get more pronounced as resources become more constrained due to population growth and as water and energy suppliers confront new challenges, including water quantity and quality associated with climate change (Intergovernmental Panel on Climate Change 2008). Understanding and accounting for the energy-water nexus is becoming increasingly important to ensure that natural resource policies and plans lead to sustainable and affordable results. Using an integrated policy-making approach to make the system more resilient and sustainable would be a significant step forward.

\section{ELECTRICITY GENERATION FROM TEXAS POWER PLANTS}

Electricity is used for many different aspects of society. Electricity consumption for residential purposes - lighting and heating homes, and powering appliances - is $37 \%$ of the total electricity use in the U.S. and 33\% in Texas (Fig. 1). Though electricity powers some transportation, the amount used is negligible for both the U.S. and Texas. Since Texas is home to many energy-intensive refining, chemical, and manufacturing facilities, industrial electricity use is higher, as a percentage of total use, than in the country as a whole (Fig. 1).

Fig. 2 shows the percentages of electricity generation by fuel source for both the U.S. and Texas. The discrepancies in total electricity between Figs. 1 and 2 are due to energy losses during distribution (that is, 400 billion $\mathrm{kWh}$ of electricity were generated in Texas in 2006, but only 380 billion $\mathrm{kWh}$ were consumed because of losses between the point of generation and the point of end use). The Texas fuel mix differs from that of the U. S. in terms of the two major primary energy sources: coal and natural gas. Though coal produces nearly half of the electricity generated nationwide, it accounts for $37 \%$ of electricity generated in Texas. Nearly half of the electricity generated in Texas is from natural gas, compared to the national average of $20 \%$. Consequently, electricity generation in Texas is less carbon-intensive per megawatt-hour than the average generation in the rest of the nation.

This mix of sources for electricity generation changes gradually as new power plants and new power generation technologies come on-line. For example, the renewable source in 2006 included wind power, along with other sources like hydropower and solar power. In 2008, Texas wind turbines generated more than $14 \mathrm{TWh}$ of electricity (3.6\% of Texas' total) - more than the total renewable generation in 2006 (Energy Information Administration 2009a).

As a highly populated, industry-intensive state, Texas requires significant amounts of both energy and water. Texas' 258 power plants have the capacity to produce more than 110 gigawatts $(\mathrm{GW})$ of power. Actual generation totals about $400 \mathrm{TWh}$, or $400 \times 10^{9} \mathrm{kWh}$, annually (King et al. 2008). These power plants are located mostly in east Texas, but a few large plants are located in west Texas (Fig. 3).

\section{WATER CONSUMPTION AND WITHDRAWALS OF TEXAS POWER PLANTS}

The typical thermoelectric power plants use nuclear or fossil fuels to heat high purity water into steam, which then turns a turbine connected to a generator, producing electricity. The steam is then condensed back into water to continue the process again in a closed loop. This condensation requires cooling by 
Fig. 1. United States (left) and Texas (right) electricity consumption, in percent, by sector for 2006 (Energy Information Administration 2008, Energy Information Administration 2009b). Texas uses a larger percentage of electricity for industrial purposes than does the United States as a whole. (kWh: kilowatt-hours)

\section{U.S. Electricity Consumption by Sector} (Total: 3,700 billion $\mathrm{kWh}$ )

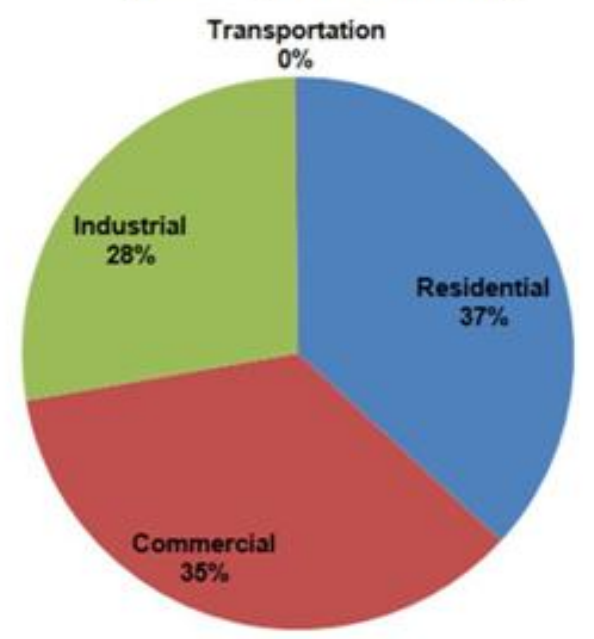

\section{Texas Electricity Consumption by Sector} (Total: 380 billion $\mathrm{kWh}$ )

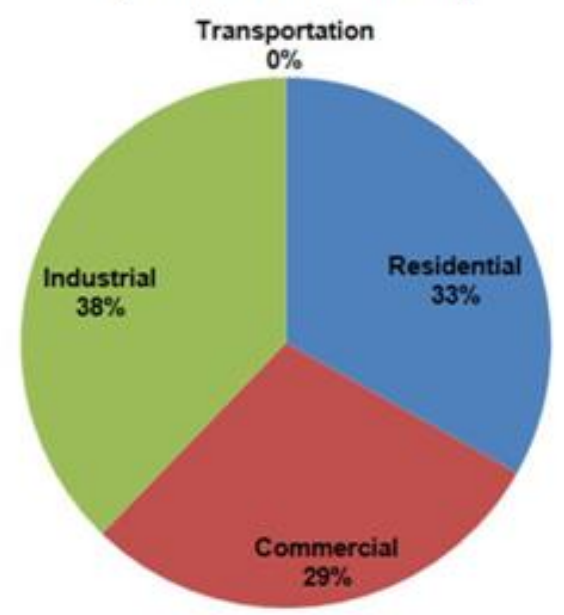

use of water, air, or both. The energy efficiency of the turbine in converting steam into electric energy depends in part on the effectiveness of the steam condensation process. That is, the efficiency of the power plant depends on its ability to cool its steam loop. The quantity of water required for cooling depends on the type of fuel, power generation technology, and cooling technology. Fig. 4 shows a diagram of a typical coal plant and how several types of cooling technologies can be combined to result in different water consumption and withdrawal.

The cooling technologies shown in Fig. 4 represent different methods of condensing steam in the power plant. Open-loop cooling, or once-through cooling, withdraws large volumes of water from a source and uses it once through a heat exchanger for cooling. As a result, open-loop cooling has small water consumption or water evaporated such that it is not directly reusable. Closed-loop cooling using cooling towers or cooling reservoirs withdraws much smaller volumes of water and recycles it for additional cooling through evaporation. This additional evaporation results in higher water consumption rates than those associated with openloop cooling. An alternative to wet cooling is aircooling using fans. Air-cooling blows air across steam tubes to remove heat and condense steam. While air-cooling uses no water, air is less efficient at removing heat, thus power generation efficiency decreases when using air-cooling.

Even some power plants that do not operate with a steam cycle (i.e., gas turbines) require a small amount of cooling for various components. Fuels such as coal and uranium also require water for the mining process. Tables 1 and 2 list the water withdrawal and consumption ranges for various combinations of fuel and cooling technologies.

As shown in Fig. 3, most power plants are located in the eastern half of the state to be close to population centers, lignite resources, and cooling water. Texas rivers generally flow to the southeast, and east Texas receives more rainfall than west Texas, which results in additional surface water availability in the eastern half of the state. More than 
Fig. 2. United States (left) and Texas (right) electricity generation, in percent, by primary energy source for 2006 (Energy Information Administration 2008, Energy Information Administration 2009b). While nearly half of the electricity generated nationwide is from coal, nearly half of the electricity generated in Texas is from natural gas. Here, renewable includes traditional hydro power, solar, and wind power.

(kWh: kilowatt-hours)

\section{U.S. Electricity Generation by Source} (Total: 4,100 billion $\mathrm{kWh}$ )

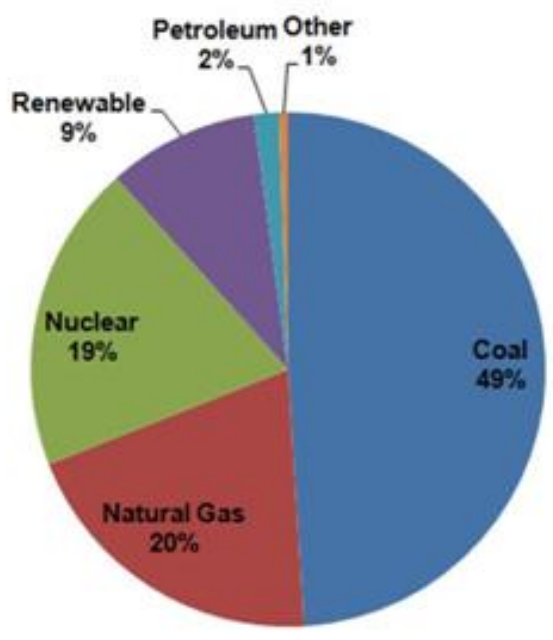

\section{Texas Electricity Generation by Source} (Total: 400 billion $\mathrm{kWh}$ )

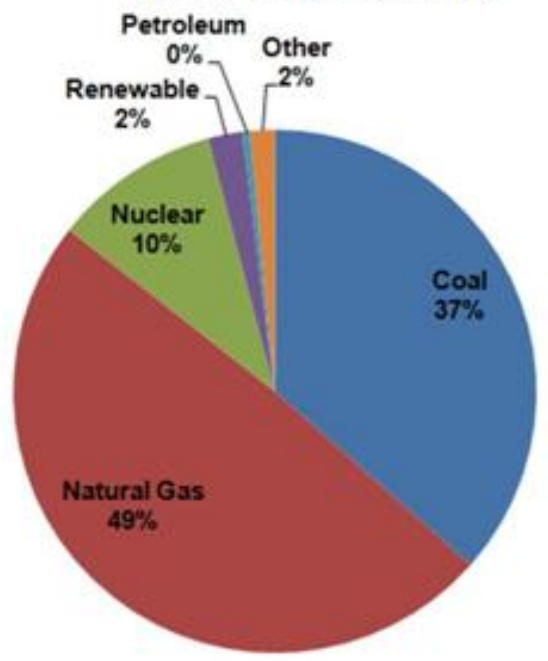

$90 \%$ of Texas power plants are cooled using surface water or air-cooling (including natural gas combustion turbines in isolation or as part of combined cycle power plants). Of Texas power plants, 22 plants with generation capacities totaling 9400 megawatts (MW) - approximately $8 \%$ of total Texas generation capacity and 27 TWh (7\%) of Texas generation - use groundwater for cooling with cooling towers, most of those being located in the panhandle region of west Texas. As a result of the arid climate and the heavy reliance on cooling towers in this region, the average consumption rate for these 22 plants is $77 \%$ higher than the overall Texas average (180 liters per megawatt-hour (L $\left.[\mathrm{MWh}]^{-1}\right)$ ).

Thermoelectric power plants in Texas consume water for cooling (Fig. 5). Water consumption by Texas power plants totals more than 595,000 ML annually - enough water for the municipal use of more than three million people for a year, each using $530 \mathrm{~L}$ per person per day. This total was estimated based on data regarding water intake, diversion, and return flows from the Texas Water Development Board and Texas Commission on Environmental Quality (King et al. 2008). As expected, high values of water consumption per kilowatt-hour correspond to closed-loop cooling systems, which consume a large percentage of water withdrawn.

Power plants are responsible for an estimated $2.5 \%$ of the total water consumption for Texas (Texas Water Development Board 2007). This percentage reflects water consumption only and does not include nonconsumptive water withdrawals or water lost through natural evaporation from cooling reservoirs. Water withdrawal for cooling is much larger than water consumption, especially with open-loop cooling. Understanding and accounting for the differences between consumption and withdrawal is important for accurate planning and management. Specifically, the large amounts of water that need to be withdrawn for cooling introduce vulnerability into the system: if drought creates a water shortage, then power plants might be forced to shut down. Furthermore, reservoirs 
Fig. 3. Electricity generation capacity (kilowatts [kW]) from Texas power plants (King et al. 2008). Total electricity generation capacity statewide is more than 110 gigawatts $(110,000,000 \mathrm{~kW})$.

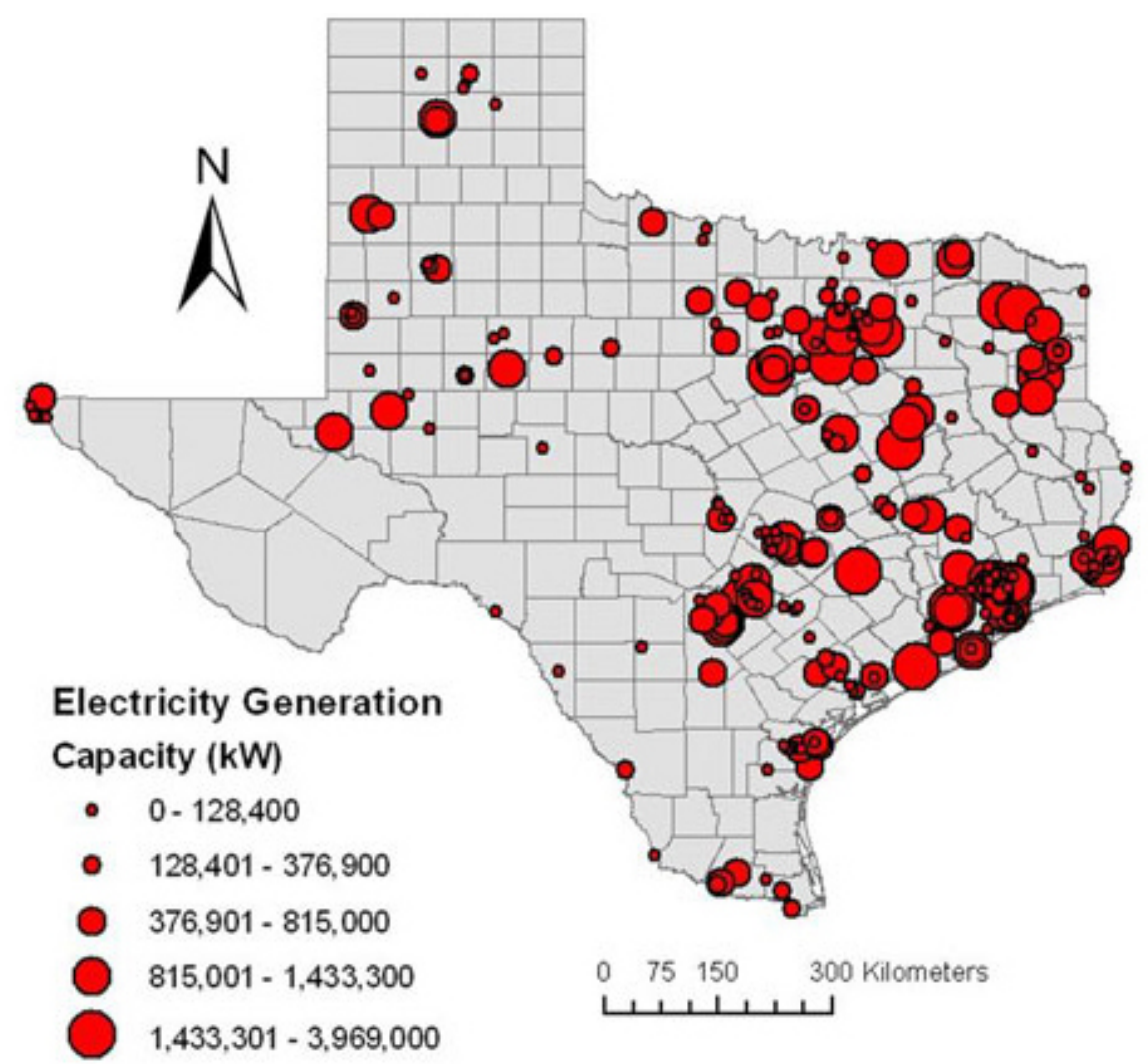

used for closed-loop cooling confine water that otherwise could be used for other purposes downstream and could allow for instream flows and evaporative losses.

No power plants in Texas have had to reduce their electric output due to water shortages. However, there are community concerns that water availability should be a constraint when siting new power plants in Texas. One company continues to hold on to water rights to preserve the viability of a potential future nuclear plant project (Caputo 2009). Also, a proposed coal plant in west Texas (a plant that includes carbon dioxide $\left[\mathrm{CO}_{2}\right]$ capture to sell for enhanced oil recovery) has had difficulty obtaining rights to a quantity of water commensurate with an air-cooled or hybrid wet-dry system (Gray 2009).

\section{ENERGY FOR WATER AND WASTEWATER TREATMENT SYSTEMS IN TEXAS}

According to the State Water Plan, public water supply in Texas currently accounts for approximately 5.6 million ML of water each year and is projected to grow to 10.2 million ML/yr by 2060 (Texas Water Development Board 2007). Electricity use for Texas water and wastewater systems, however, is not currently measured directly. Consequently, electricity consumption for Texas water systems must be estimated based on national average electricity use per volume of water treated, as shown in Table 3. Based on current water flow rates from the State Water Plan and national average values for energy per water volume treated, Texas uses an estimated 2.1-2.7 TWh/yr for public water supply systems, accounting for about 1.5$1.9 \%$ of Texas' industrial electricity use and $0.5-$ 
Fig. 4. Basic schematic of a pulverized coal-fired power plant with percentages of energy flow and median water withdrawal and consumption for cooling per megawatt-hour (MWh) of electricity generated (Goldstein and Smith 2002a, Masters 2004). Only 33\% of the incoming fuel is converted to electricity.

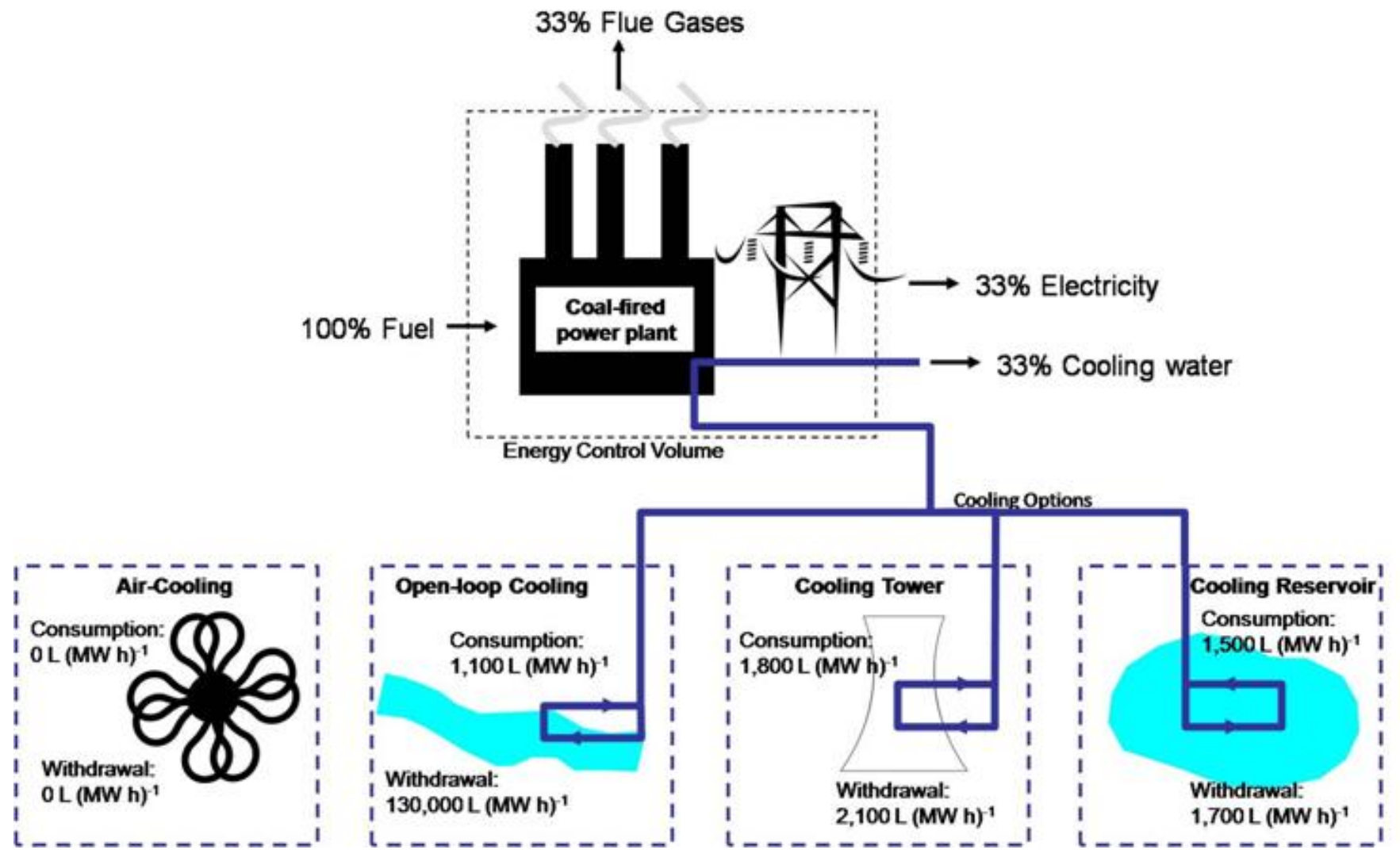

$0.7 \%$ of total electricity use annually. This percentage of Texas electricity use for water treatment is lower than the national percentages for electricity use for water systems due to the overall higher electricity consumption in Texas industries (Energy Information Administration 2009b). Directly measuring electricity consumption of Texas water treatment plants, as well as the electricity needed for source water collection, conveyance, and in-home uses would provide a more reliable picture of energy requirements for water treatment.

Municipal wastewater treatment plants are generally distributed according to population, and are thus concentrated in eastern and central Texas (Fig. 6). More than $76 \%$ of the municipal wastewater treatment plants in Texas each treat flows of 3.8 ML per day (ML/d) or less. Larger wastewater treatment plants that serve cities such as Dallas, Houston, San Antonio, and Austin, however, treat flows up to $760 \mathrm{ML} / \mathrm{d}$.

Similar to water treatment plants, information on energy use at Texas wastewater treatment plants is not readily available. Thus, electricity for wastewater treatment must be estimated based on national average values for energy per volume of wastewater treated. Energy required per volume of wastewater treated varies with wastewater treatment plant capacity, as shown in Table 4. Total energy for wastewater treatment was estimated using energy per volume of wastewater treated for specific plant capacities and treatment technologies. 
Table 1. Water withdrawal reported volumes for different fuels and cooling technologies (Gleick 1994, Goldstein and Smith 2002a, Woods et al. 2007, National Renewable Energy Laboratory 2008). Air-cooling requires negligible water and is compatible with all of the technologies listed.

\begin{tabular}{|c|c|c|c|c|c|}
\hline & \multicolumn{5}{|c|}{ Cooling Technologies - Water Withdrawal $\left(\mathrm{L}[\mathrm{MWh}]^{-1}\right) \dagger$} \\
\hline & Open-Loop & $\begin{array}{l}\text { Closed-Loop } \\
\text { Reservoir }\end{array}$ & $\begin{array}{l}\text { Closed-Loop } \\
\text { Cooling Tower }\end{array}$ & Hybrid Cooling & Air-Cooling \\
\hline Coal & $\begin{array}{c}132,000 \\
( \pm 57,000)\end{array}$ & $\begin{array}{c}1700 \\
( \pm 500)\end{array}$ & $\begin{array}{l}2100 \\
( \pm 200)\end{array}$ & between & $<400$ \\
\hline Nuclear & $\begin{array}{l}161,000 \\
( \pm 66,000)\end{array}$ & $\begin{array}{c}3000 \\
( \pm 1,100)\end{array}$ & $\begin{array}{c}3600 \\
( \pm 600)\end{array}$ & between & $<400$ \\
\hline $\begin{array}{l}\text { Natural Gas Combustion } \\
\text { Turbine }\end{array}$ & negligible & negligible & negligible & negligible & negligible \\
\hline Natural Gas Combined-Cycle & $\begin{array}{c}52,000 \\
( \pm 24,000)\end{array}$ & $\begin{array}{c}600^{\ddagger} \\
( \pm 100)\end{array}$ & 900 & between & $<400^{\ddagger}$ \\
\hline $\begin{array}{l}\text { Integrated Gasification } \\
\text { Combined-Cycle }\end{array}$ & not used & not used & $\begin{array}{l}1500^{\ddagger} \\
( \pm 400)\end{array}$ & between & $<400^{\ddagger}$ \\
\hline Concentrated Solar Power & not used & not used & $\begin{array}{l}3200^{\ddagger} \\
( \pm 300)\end{array}$ & between & $<400^{\ddagger}$ \\
\hline Wind & none & none & none & none & none \\
\hline Photovoltaic Solar & none & none & none & none & none \\
\hline
\end{tabular}

$\dagger \mathrm{L}[\mathrm{MWh}]^{-1}$ : liters per megawatt-hour

\$Estimated based on withdrawal and consumption ratios

Using this approach, it is estimated that 1.8-2.0 $\mathrm{TWh} / \mathrm{yr}$ is required for wastewater systems in Texas, which amounts to $1.2-1.3 \%$ of Texas' industrial electricity use and $0.4-0.5 \%$ of Texas' total electricity use.

Combining the estimates of electricity use for water and wastewater treatment, Texas water and wastewater systems require 3.9-4.7 TWh of electricity annually. With current electricity generation of approximately $400 \mathrm{TWh} / \mathrm{yr}$, water and wastewater systems use $1.0-1.2 \%$ of Texas' total electricity and $2.7-3.2 \%$ of its industrial electricity use. Note that this estimate for electricity consumption does not include end uses (such as water heaters, dishwashers, pool pumps, etc.). Other national and statewide estimates indicate that energy consumption at end use can be three to five times higher than the consumption by water and wastewater treatment plants (California Energy Commission 2005, Griffiths-Sattenspiel and Wilson 2009). Our estimates and analysis of energy for water and wastewater treatment in Texas are hindered by a lack of data. Direct measurement and reporting of electricity use in Texas water and wastewater treatment plants would provide a more appropriate basis for planning, management, and policy.

New water supply proposals based on moving water long distances - 46 total major water conveyance projects proposed by Texas regional water planning groups - create potentially significant energy demands, though insufficient information exists at 
Table 2. Water consumption reported volumes for different fuels and cooling technologies (Gleick 1994, Goldstein and Smith 2002a, Woods et al. 2007, National Renewable Energy Laboratory 2008). Air-cooling requires negligible water and is compatible with all of the technologies listed.

\begin{tabular}{|c|c|c|c|c|c|}
\hline & \multicolumn{5}{|c|}{ Cooling Technologies - Water Consumption $\left(\mathrm{L}[\mathrm{MWh}]^{-1}\right) \dagger$} \\
\hline & Open-Loop & $\begin{array}{l}\text { Closed-Loop } \\
\text { Reservoir }\end{array}$ & $\begin{array}{l}\text { Closed-Loop } \\
\text { Cooling Tower }\end{array}$ & Hybrid Cooling & Air-Cooling \\
\hline Coal & 1100 & $\begin{array}{c}1500 \\
( \pm 400)\end{array}$ & 1800 & between & $\begin{array}{c}200 \\
( \pm 40)\end{array}$ \\
\hline Nuclear & 1500 & $\begin{array}{c}2400 \\
( \pm 850)\end{array}$ & 2700 & between & $\begin{array}{c}200 \\
( \pm 40)\end{array}$ \\
\hline $\begin{array}{l}\text { Natural Gas Combustion } \\
\text { Turbine }\end{array}$ & negligible & negligible & negligible & negligible & negligible \\
\hline Natural Gas Combined-Cycle & 400 & $\begin{array}{c}500^{\ddagger} \\
( \pm 80)\end{array}$ & 700 & between & $\begin{array}{l}200^{\ddagger} \\
( \pm 40)\end{array}$ \\
\hline $\begin{array}{l}\text { Integrated Gasification } \\
\text { Combined-Cycle }\end{array}$ & not used & not used & $\begin{array}{l}1300^{\ddagger} \\
( \pm 400)\end{array}$ & between & $\begin{array}{l}200^{\ddagger} \\
( \pm 40)\end{array}$ \\
\hline Concentrated Solar Power & not used & not used & $\begin{array}{c}3200 \\
( \pm 300)\end{array}$ & between & $\begin{array}{c}300^{\ddagger} \\
( \pm 40)\end{array}$ \\
\hline Wind & none & none & none & none & none \\
\hline Photovoltaic Solar & none & none & none & none & none \\
\hline
\end{tabular}

$\dagger \mathrm{L}[\mathrm{MWh}]^{-1}$ ): liters per megawatt-hour

\$Estimated based on withdrawal and consumption ratios

this time to quantify the increased electrical generation capacity required for specific projects (Texas Water Development Board 2007). Detailed geographic data are required to quantify the energy embedded in long distance water conveyance and interbasin transfer systems but they were not available for this study. In addition, increased public water supply use (however the water is supplied) will result in increased electricity use for water treatment and distribution and for wastewater treatment.

\section{FUTURE ENERGY AND WATER USE IN TEXAS}

The population of Texas is predicted to double by 2060 , from the current 23 million to about 46 million
(Texas Water Development Board 2007). Without increasing efficiency or implementing significant energy and water conservation practices, energy and water consumption are likely to grow under a business-as-usual scenario. The central challenge for Texas policy-makers is to determine how to balance this projected new demand with the need to (1) ensure sustainable use of limited water resources, (2) provide power in a manner that protects air quality, and (3) meet the requirements of anticipated national legislation to address climate change. This challenge is made more difficult by the interconnections between water and energy and the trade-offs involved in selecting various power and water supply options. 
Fig. 5. Water consumption for thermoelectric power generation in Texas (King et al. 2008). Total water consumption for electricity generation statewide is more than 595,000 megaliters annually - enough water for three million people for a year, each using 530 liters per person per day. (L/kWh: liters per kilowatt-hour)

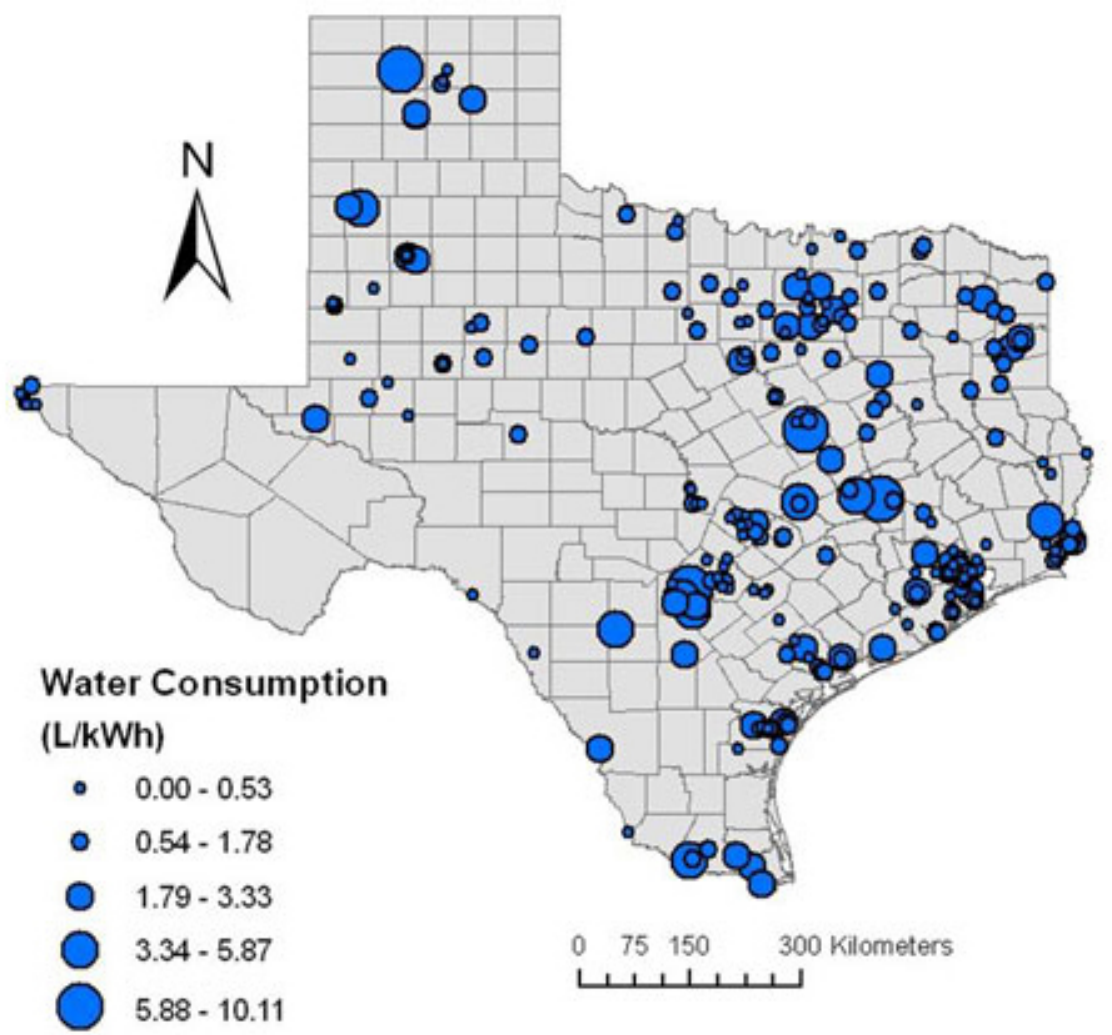

\section{Electricity demand projections}

Using the current fuel mix for power generation in Texas, a business-as-usual power demand scenario was projected to 2018 (Fig. 7) (Webber et al. 2008). This scenario does not account for significant reductions in demand that could be attained with the implementation of advanced efficiency measures, nor does it reflect changes in fuel mix that would likely result from a federally mandated carbon capand-trade or carbon tax system.

In the business-as-usual scenario including current power generation and announced future power plants, total electricity generation increases to nearly $490 \mathrm{TWh}$ annually by 2018 from $400 \mathrm{TWh}$ today. The fuel mix for this scenario assumes nuclear power plants in the permitting phase will be built (shown as an increase in generation between 2015 and 2016). It also assumes rapidly expanding wind-generated electricity to $12.5 \%$ of total generation by 2018 from $3.6 \%$ in 2008 , avoiding approximately $91,000 \mathrm{ML}$ of water consumption compared to the Texas mix of thermoelectric power generation (see Webber et al. 2008 for details of assumptions). Since natural gas power plants primarily represent peak electricity load generating potential, electricity generation from these plants remains relatively constant throughout the projected scenario and mitigates intermittency of the increased penetration of wind power. The on-site industrial category represents electricity that is generated at industrial facilities for their own use, but the industrial sector also buys electricity from the electric grid. 
Table 3. National average electricity use for water collection and treatment using different water treatment technologies (Goldstein and Smith 2002b, California Energy Commission 2005). Distribution represents additional energy use.

\begin{tabular}{ll}
\hline \hline Water Collection and Treatment & $\mathrm{kWh} / \mathrm{ML} \dagger$ \\
\hline Surface water treatment & 60 \\
Groundwater treatment & 160 \\
Brackish groundwater treatment & $1000-2600$ \\
Seawater desalination & $2600-4400$ \\
\hline
\end{tabular}

$\dagger \mathrm{kWh} / \mathrm{ML}$ : kilowatt-hours per megaliter

A high renewables fuel mix scenario that anticipates rapid market penetration of renewable power sources is shown in Fig. 8 (Webber et al. 2008). Coal-generated electricity is projected to decrease somewhat under a high renewables scenario if a cap on carbon is established, while both wind (18\%) and nuclear $(23 \%)$ power are projected to increase dramatically by 2018 . The scenario in Fig. 8 does not account for significant reductions in demand that could be attained with the implementation of advanced efficiency measures, nor does it account for other regulatory or economic factors, or other factors that might affect fuel mix (e.g., the availability of financing or waste disposal for nuclear plants).

It is difficult to predict how the various electricity generation scenarios in Figs. 7 and 8 might affect water demand, since such demand is highly dependent not only on the fuel mix but also on the type of cooling technology selected for particular plants. It is clear, however, that without implementation of advanced energy efficiency measures, electricity demand in Texas is likely to grow rapidly, and there will be pressure to supply part of that new demand through nuclear plants, even under a high renewables scenario. This scenario could have significant implications for water supply since nuclear plants withdraw and consume more water than similarly sized fossil fuel plants. While no U.S. or Texas nuclear power plants currently use air-cooling, the Palo Verde nuclear power plant in Arizona uses reclaimed water, and there is ongoing research by organizations (e.g., the
Electric Power Research Institute) that are investigating the use of air-cooling for nuclear and other steam-based power plants.

Large-scale carbon capture and storage (CCS) systems are also a possibility for the future, especially in response to potential carbon legislation. Carbon dioxide can be captured from flue gases by retrofitting existing pulverized coal power plants with $\mathrm{CO}_{2}$ scrubbers. Typical scrubbers use chemical solvents to capture $\mathrm{CO}_{2}$. The solvent then undergoes thermal cycling to remove the $\mathrm{CO}_{2}$, which is then transported and stored (World Coal Institute 2007). CCS systems allow for power generation using coal while concurrently reducing carbon emissions to the atmosphere. These systems will, however, increase water consumption rates of power plants, in terms of liters per net generation due to (1) the parasitic power loss from the use of steam to regenerate the solvent, which reduces the amount of electricity that is generated, (2) the power required to compress $\mathrm{CO}_{2}$ to a supercritical state for pipeline transport and subsurface injection, and (3) the additional cooling requirements of the carbon stripping process (King et al. 2008).

If one assumes that a traditional pulverized coal power plant with $\mathrm{CO}_{2}$ capture produces the same net power output as an equivalent plant without capture, then there will be an approximate 50-90\% higher cooling load and a commensurate increase in water consumption if using wet cooling. Approximately $25-40 \%$ more power is required to operate the capture processes, and it is unclear 
Fig. 6. Municipal wastewater treatment flow for Texas wastewater treatment plants (Environmental Protection Agency 2008, Texas Commission on Environmental Quality 2008). More than 76\% of the wastewater treatment plants in Texas are small, using less than 3.8 megaliters per day (ML/d).

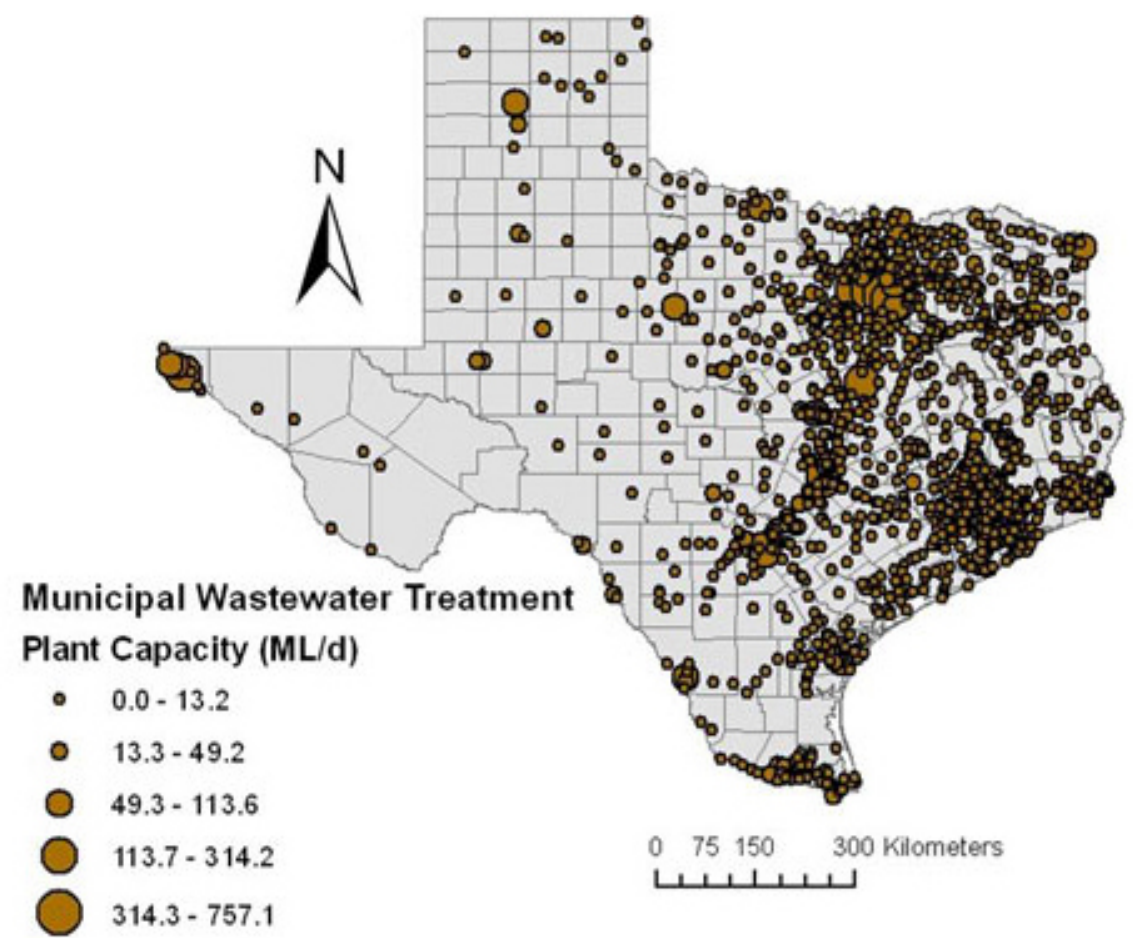

whether this power would come from burning more coal or from other sources.

Under proposed laws seeking reductions in $\mathrm{CO}_{2}$ emissions from the power sector, the water consumption for electricity can vary tremendously depending upon the mix of fuels (Fig. 9). Assuming steady growth in electricity generation in Texas for the next 50 years, water consumption for electricity in 2060 could vary between 2,000,000 ML (for a scenario where natural gas provides only $20 \%$ of total electricity) and 1,500,000 ML (for a scenario where natural gas provides $40 \%$ of total electricity) (King et al. 2008). Assuming no $\mathrm{CO}_{2}$ constraint arises, using the same suite of fuel technologies consumes $40 \%$ less and $25 \%$ less water, respectively. Constraints on $\mathrm{CO}_{2}$ and other air quality concerns might change the fuels and technologies used for electricity generation. Thus, trade-offs between air quality, electricity generation, and water consumption will play an increasingly important role in the future.
For Integrated Gasification Combined-Cycle (IGCC) plants based on GE Radiant-Convective (1700 L (MWh) $)^{-1}$ ), GE-Quench (1900 L (MWh $\left.)^{-1}\right)$, Conoco-Phillips (1600 L (MWh $\left.)^{-1}\right)$, or Shell $(1700$ $\left.\mathrm{L}(\mathrm{MWh})^{-1}\right)$ gasifiers, the water use is substantially less per unit of produced electricity than that of a typical pulverized coal power plant at $132,000 \mathrm{~L}$ $(\mathrm{MWh})^{-1}$ for open-loop cooling (Klett et al. 2005). An additional 10-20\% more water is required for adding carbon capture to these IGCC reference plants, which is small relative to that for pulverized coal plants (National Energy Technology Laboratory 2007). As a result, an IGCC plant with carbon capture has a water usage that is one third less than a traditional pulverized coal plant without capture (Woods et al. 2007).

Fig. 9 illustrates the uncertainty in water consumption estimates for future electricity generation in Texas. Projections of low (20\% of total electricity generation) and high $(40 \%$ of total electricity generation) natural gas-fired electricity, 
Table 4. Variation in unit electricity consumption for different sizes of wastewater treatment plants (Goldstein and Smith 2002b). Larger wastewater treatment plants exhibit economies of scale with lower energy requirements per volume of wastewater treated.

\begin{tabular}{ccccc}
\hline \hline & \multicolumn{4}{c}{ Electricity Consumption (kWh/ML) $\dagger$} \\
\cline { 2 - 5 } \begin{tabular}{c} 
Wastewater Treatment Plant $\begin{array}{c}\text { Size } \\
(\text { ML/d) })\end{array}$ \\
\cline { 2 - 5 }
\end{tabular} & Trickling Filter & Activated Sludge & $\begin{array}{c}\text { Advanced } \\
\text { Wastewater } \\
\text { Treatment }\end{array}$ & $\begin{array}{c}\text { Advanced Wastewater } \\
\text { Treatment with } \\
\text { Nitrification }\end{array}$ \\
\hline 3.8 & 480 & 590 & 690 & 780 \\
19 & 260 & 360 & 420 & 510 \\
38 & 230 & 320 & 370 & 470 \\
76 & 200 & 290 & 340 & 440 \\
190 & 180 & 280 & 320 & 420 \\
380 & 180 & 270 & 310 & 410 \\
\hline
\end{tabular}

$\dagger \mathrm{kWh} / \mathrm{ML}$ : kilowatt-hours per megaliter

$\$ \mathrm{ML} / \mathrm{d}$ : megalitres per day

combined with and without capture of carbon dioxide for fossil fuel power plants, led to the four scenarios shown in Fig. 9 (King et al. 2008). Since natural gas combustion turbines consume negligible quantities of water, both high natural gas scenarios consume less water than the corresponding low natural gas scenario. This difference increases as carbon capture is implemented for electricity generation due to the increase in water consumption per net generation for CCS systems. As a result, market conditions and/or policy decisions that potentially change the electricity fuel mix and incorporate CCS systems will change the amount of water consumed for electricity.

\section{Conservation of energy and water}

Given the energy-water interrelationships, water conservation and energy conservation are synonymous and are a good starting point for robust policy formulation. Specifically, conserving water reduces the electricity needed to collect, treat, and distribute water, as well as to convey, treat, and discharge wastewater, in many situations.
Conserving electricity saves energy and also the water needed to cool power plants while that electricity is generated.

Because electricity consumption is approximately linear to the amount of water and wastewater that are treated, distributed, and collected, reducing water flows through these energy-intensive steps reduces the amount of electricity that is required. If municipal water use and wastewater flows are reduced by $10 \%$, the state's demand for electricity would go down by 320-490 million $\mathrm{kWh}$ in the water/wastewater sectors alone. Improvements to water infrastructure can also effectively conserve both energy and water by decreasing water loss, which contains embedded energy for treatment and pumping. Such infrastructure investments can be a significant method of conserving both energy and water. End use energy consumption for water heating might also drop depending on whether water conservation is achieved through outdoor or indoor use. Conversely, reducing energy demand also reduces demand for cooling water at power plants: reducing overall electricity generation in Texas by $10 \%$ could reduce water consumption by as much 
Fig. 7. Projections for Texas electricity generation under a business-as-usual scenario show growth to 490 terawatt-hours (TWh) by 2018 (Webber et al. 2008).

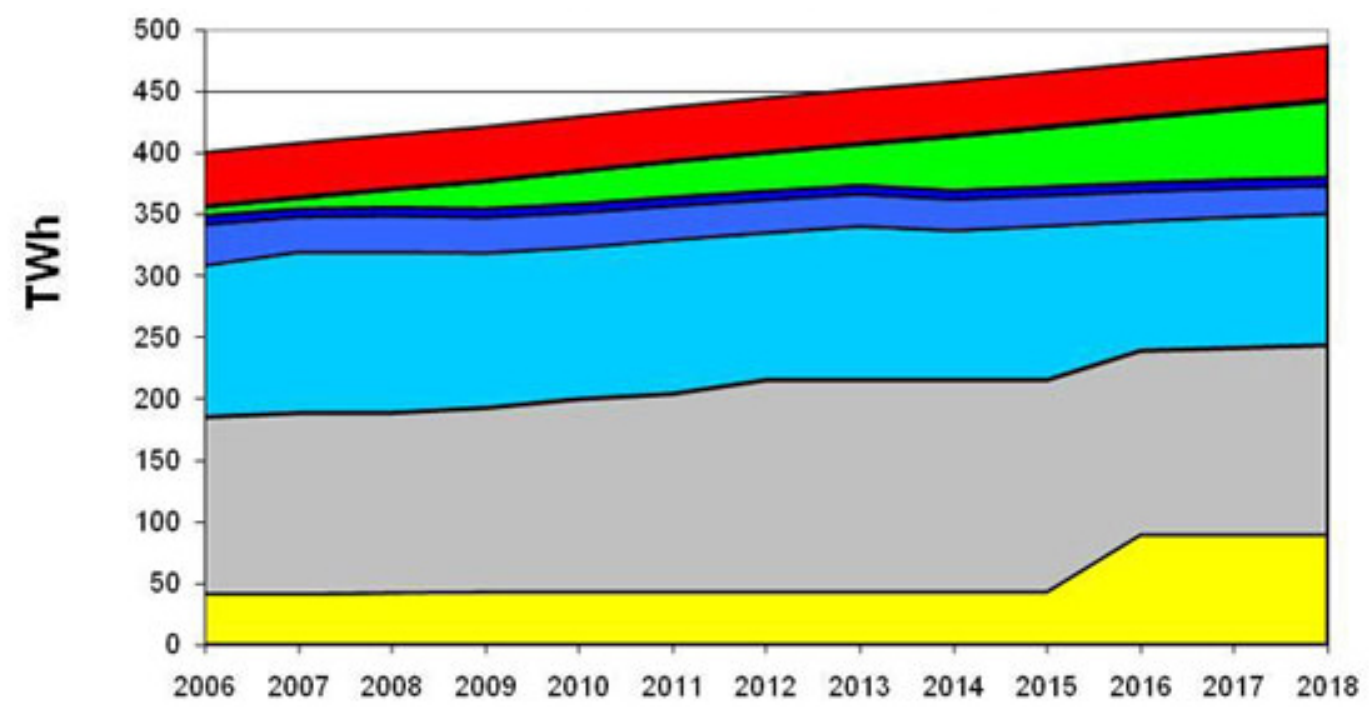

\begin{tabular}{|lll|}
\hline$\square$ Nuclear & $\square$ Coal & $\square$ Natural gas combined-cycle \\
$\square$ Natural gas - steam turbine & anatural gas - gas turbine & $\square$ Wind \\
$\square$ Non-wind renewable & $\square$ On-site industrial & \\
\hline
\end{tabular}

as 57,000 million ML of water per year depending on which power plants reduce their output to accommodate the lower demand.

In addition to increased water efficiency, water reuse is an option for saving water and energy. Some water uses, such as landscape irrigation and toilet flushing, do not require water to be treated to drinking water standards. One alternative to watering lawns and flushing toilets with drinking water is to use reclaimed water. Reclaimed water is effluent from a wastewater treatment plant that is treated with an additional tertiary filtration process before reuse. Though reclaimed water is not necessarily safe for drinking, additional filtration removes contaminants that pose threats to human health during unintended exposure (Asano et al. 2007). While this additional wastewater treatment requires approximately $32 \mathrm{kWh} / \mathrm{ML}$ for tertiary filtration, use of reclaimed water saves approximately $370-480 \mathrm{kWh}$ of electricity per ML needed for collecting, treating, disinfecting, and distributing drinking water for nonpotable uses (Goldstein and Smith 2002b). In addition to saving energy, water reuse can augment existing water supplies and is generally a more cost-effective option than acquiring new water supplies (Anderson 2003). Varying levels of additional treatment are necessary, depending on the water reuse application.

Reclaimed water can also be used to artificially recharge groundwater aquifers through surface spreading and direct injection. Surface spreading applying reclaimed water to the land surface to promote water seepage and percolation into the aquifer - requires little to no additional treatment or energy due to the soil's natural filtration processes. However, direct injection - using wells to introduce reclaimed water into the aquifer water table requires additional treatment beyond advanced wastewater treatment, usually energy-intensive membrane water treatment to remove potential pathogens (Asano et al. 2007). 
Fig. 8. Projections of Texas electricity generation with a large increase in renewable energy-generated electricity (Webber et al. 2008).

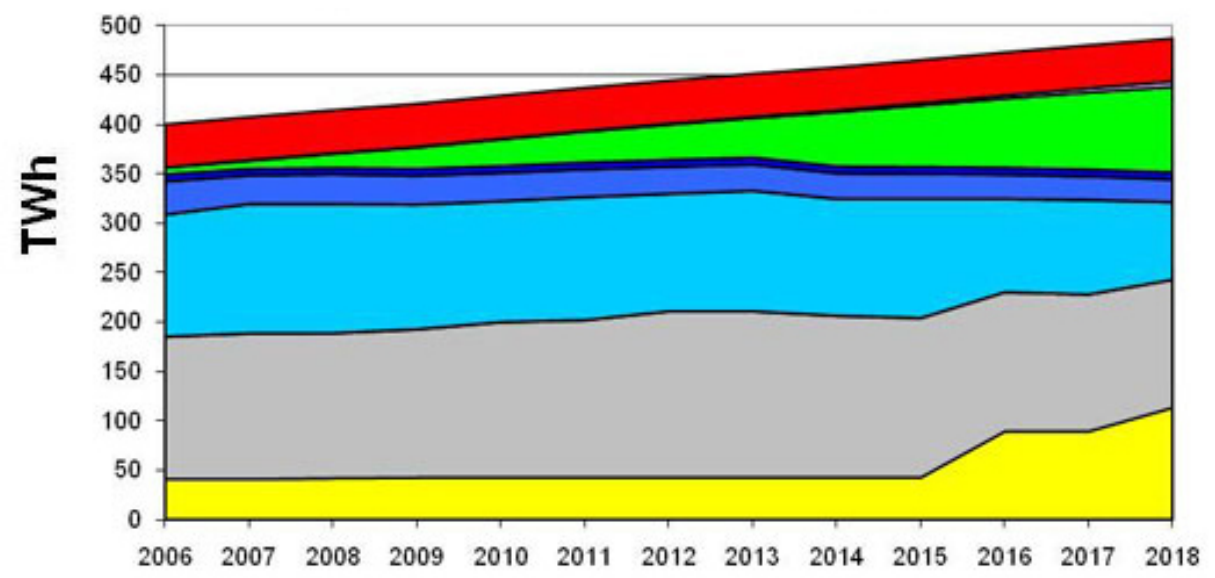

\begin{tabular}{|lll|}
\hline $\begin{array}{l}\text { Nuclear } \\
\square \text { Natural gas - steam turbine }\end{array}$ & $\square$ Coal & $\square$ Natural gas - gas turbine combined-cycle \\
$\square$ Non-wind renewable & $\square$ On-site industrial & $\square$ Wind \\
\hline
\end{tabular}

Reclaimed water can also be reused to supplement public drinking water supply. Following advanced wastewater treatment, reclaimed water is treated using membranes or other advanced technology to remove pathogens and trace contaminants and is then added to an existing surface water source, such as a reservoir, or is fed directly to a water treatment plant. Though this type of water reuse has sometimes ignited adverse public reaction regarding quality - the "toilet-to-tap" idea reclaimed water has a higher quality after membrane treatment than many raw water sources (Asano et al. 2007). In fact, drinking water sources for more than 26 million people in the United States contain between $5 \%$ and $100 \%$ treated wastewater effluent from upstream discharge during low flow periods (Anderson 2003). Some water-strained societies, such as Singapore, also use reclaimed water as a public supply without adverse health effects.

Water reuse conserves water and, in some applications, conserves energy by not treating water for nonpotable uses to drinking water standards. In other applications, additional energy-intensive treatment, such as membrane filtration, which requires up to $1100 \mathrm{kWh} / \mathrm{ML}$, is necessary to protect human health during water reuse (California Energy Commission 2005). Yet this energy investment for water reuse is still less than the energy needed for seawater desalination (2600-4400 kWh/ML) or for long-haul water transfer when water supplies are depleted (i.e., more than $1600 \mathrm{kWh} / \mathrm{ML}$ for the Colorado River Aqueduct transfer system in California [California Energy Commission 2005]).

\section{POLICY DISCUSSION}

As Texas confronts the challenges posed by climate change, including increased precipitation variability, where parts of the state are predicted to have increased droughts while other parts can expect more frequent and more severe storm events, decisions about how to supply energy and water to our state's growing population should be made in an integrated fashion. 
Fig. 9. Projected water consumption for power generation in Texas with low and high natural gas use and with and without capture of carbon dioxide (Webber et al. 2008).

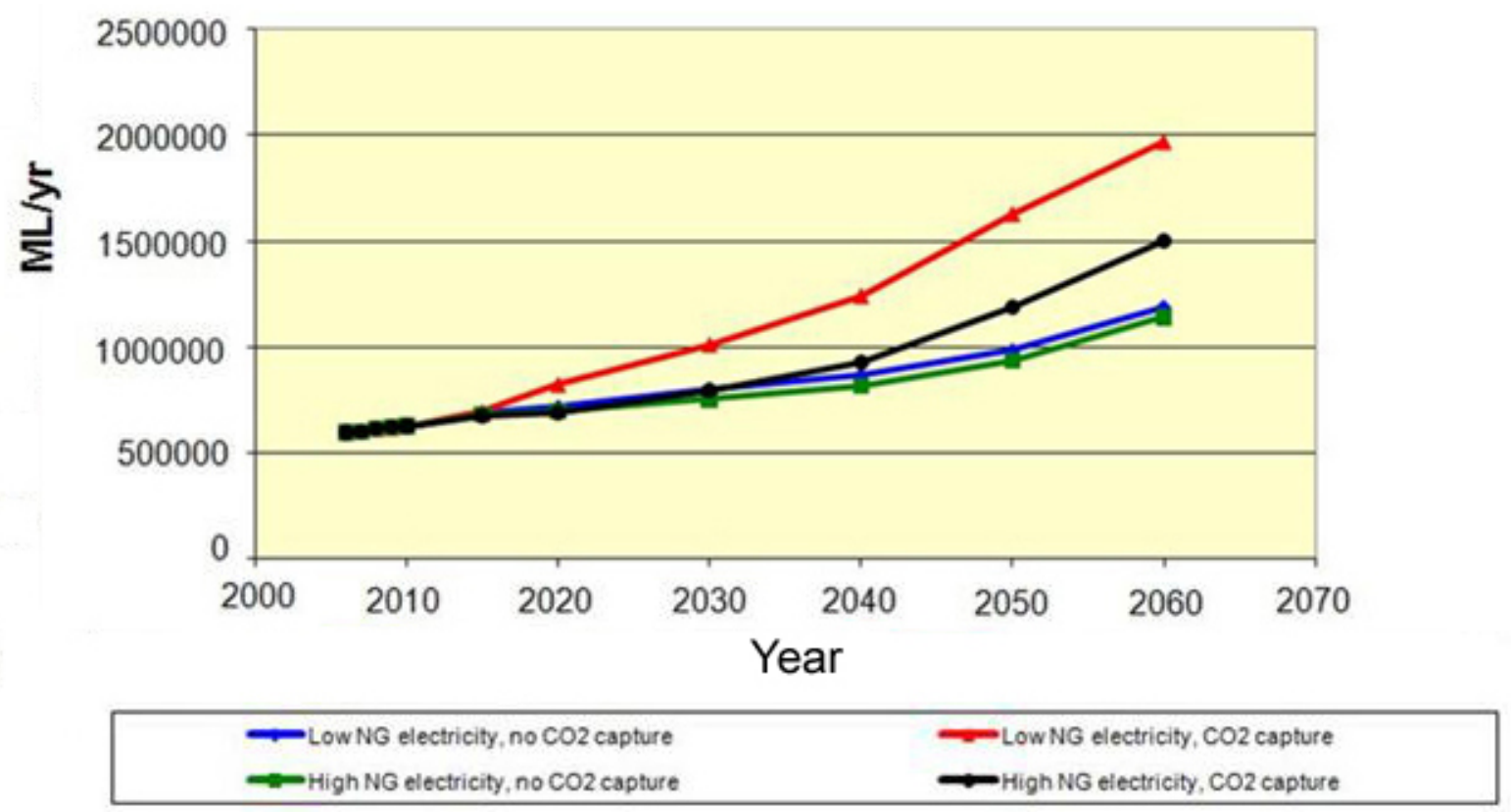

\section{Carbon, water, and energy: tensions and policy trade-offs}

Because energy and water are inextricably linked, limits or increasing demands on one resource can affect the other. Furthermore, because of the power sector's carbon emissions, increasing the energy efficiency of electric power generation both lowers these emissions and reduces water consumption. Carbon emissions in part drive climate change, which impacts the hydrological cycle, creating another linkage between energy and water. Implementation of next generation power plant technologies such as ultra-supercritical coal and IGCC plants (as well as combined-cycle natural gas technology) has the potential to increase energy efficiencies by $25-50 \%$ over those for traditional pulverized coal plants with pollution controls (Metz et al. 2005). Subsequently, the carbon emissions and water use per megawatt-hour of generated electricity could go down.

Increased efficiency in water usage can also play a role in reducing carbon emissions. Providing water for domestic, agricultural, and industrial consumption requires energy, which emits carbon. Thus, lowering water usage simultaneously lowers energy consumption, which lowers carbon emissions. Such reductions, however, have always been overwhelmed by overall growth in the usage of both water and energy. For example, over the last 50 years, the water efficiency of power production has steadily increased: water use per megawatt-hour generated has decreased. At the same time, both electric power production and the total water used for power production have steadily increased. Thus, water efficiency improvements for electricity generation are masked by overall growth in generation.

Despite the synergies of conservation, we are entering an era in which public policies designed to reduce water use for energy, such as air-cooling, may lead to increases in carbon emissions. Conversely, policies to reduce carbon emissions, such as carbon capture and sequestration, might increase water use. And, energy policies, such as promotion of alternative biofuels for transportation, have competing effects on water use. Moving 
forward, these interrelationships must be identified and understood before implementing public policy proscriptions that benefit one component of this complicated carbon-water-energy relationship while accidentally undermining another.

\section{Energy and carbon policies have mixed water impacts}

Analysis of current long-term priorities in U.S. energy policy suggests a mixed outlook for future impacts of the energy sector on water resources. The Energy Policy Act of 2005 and the Energy Independence and Security Act of 2007 both prioritized development of domestic sources of energy, including renewable power, nuclear power, and unconventional transportation fuels. In addition, the U.S. House of Representatives recently passed cap-and-trade carbon legislation as part of the American Clean Energy and Security Act of 2009. This bill is slated to go before the Senate in the near future.

Because the electric power sector is responsible for the largest withdrawals of water in the U.S., changes to the power sector because of energy and/or carbon policies can have a significant impact on the availability of water resources. Specifically, increasing the market penetration of renewable technologies such as solar photovoltaics and wind turbines will lower the use of water (per unit of electricity generated) by the power sector because those technologies do not require cooling. Concentrated solar power (CSP) systems are currently considerably more cost-effective for large-scale, centralized power generation than solar photovoltaic systems. The thermal conversion of radiant energy to electricity via a steam turbine typically requires cooling water at rates (liters per $\mathrm{kWh}$ ) higher than coal and nuclear power plants if using pure wet cooling towers. However, aircooling and hybrid cooling systems for CSP could be implemented in Texas.

The positive water effects of renewable power might also be offset by projected increases in nuclear power installations driven by carbon limits. Nuclear power is the most water-intensive form of conventional power generation. Air-cooling has yet to be used for nuclear power plants in the United States, but it is considered technically feasible. Furthermore, the economic environment that is conducive to renewable sources, namely high prices for carbon emissions and natural gas, is also good for nuclear power. Thus, it is possible that these forms of power will grow in tandem. Consequently, the net effects on water resources from future changes in the electric power sector due to carbon control policies are difficult to predict.

In addition, as noted above, $\mathrm{CCS}$ at coal plants might be an outcome of energy or carbon policies and will also have direct impacts on water withdrawal and consumption by the electric power industry. If implementation of CCS leads to construction of new power plants (to make up for lost capacity from the parasitic load of $\mathrm{CO}_{2}$ scrubbers), they might be based on more energy efficient power plant technologies such as supercritical coal and IGCC plants, all of which require less water than a typical pulverized coal power plant. If climate changedriven public policy results in new-build power plants being a mix of new power plant designs such as IGCC that have both higher water and energy efficiencies, even with carbon capture, then clearly the effect on water resources will be positive.

\section{Water policies might have detrimental carbon impacts}

Although the impact of long-term energy policies on water consumption is not clear, some water policies under consideration may have detrimental impacts on carbon emissions. These policies include (1) a push for new water supply from distant, lowquality sources, and (2) stricter treatment standards for water and wastewater.

Communities may turn to desalination (a water supply not affected by drought) to meet future increases in water demand. However, with current technologies, this stability comes with a large energy cost. In Texas, desalination of brackish water is already underway or is being implemented as a portion of the public water supplies for the cities of San Antonio and El Paso, and is under consideration by other municipalities (Texas Water Development Board 2009). No current U.S. policies require use of renewable electricity for desalination facilities.

Finally, more stringent treatment standards for drinking water quality and wastewater may be added to federal regulations, in particular to remediate the presence of pharmaceuticals and other contaminants for which there are no current standards (Donn et al. 2008). Water treatment to 
remove low concentration pollutants is typically an energy-intensive process, requiring activated sludge or further advanced treatment (KasprzykHordern et al. 2009). Thus, raising the treatment standards leads to increased energy consumption by water and wastewater treatment plants, which nominally yields increased carbon emissions.

\section{Proposed energy-water legislation}

Although this is a somewhat new topic for politicians, the energy-water nexus has already been included in both state and federal legislation. Texas proposed House Bill 4206 would require an air permit applicant who constructs an electric generating facility to demonstrate that a sufficient amount of water is available for use in connection with the operation of the facility. Specifically, they would need to make their water plans publicly available at the time of the air permit process. Traditionally, the air permit and water permit are handled separately and in that order, so stakeholders are not often aware of the impact the future plant will have on their local water resources. This bill was left pending in committee at the end of session; however, this or similar bills will likely be introduced in the future because the interest in this topic has grown considerably in a relatively short time period.

On the federal level, Senator Bingaman's Energy and Water Integration Act of 2009 (S. 531) is currently working its way through the legislative process. This bill's primary goal is to fix data gaps and understand the energy-water connection more fully. It directs the Secretary of Energy to enter into an arrangement with the National Academy of Sciences to conduct an in-depth analysis of the impact of energy development and production on U.S. water resources. It requires the study to include a life cycle assessment of the quantity of water withdrawn and consumed in the production of transportation fuels or electricity and to identify the best available technologies and related strategies to maximize water and energy efficiency in the production of electricity by each type of generation, including coal, oil, natural gas, hydropower, CSP, and nuclear.

In addition, the bill seeks to examine the quantities of energy used in water storage and delivery operations in major reclamation projects. It orders the research, development, and demonstration activities to develop technologies and methods that promote brackish groundwater desalination as a viable method to increase water supply in a costeffective manner. Finally, it requires the development of an Energy-Water Research and Development Roadmap. The bill was referred to the Senate Energy and Natural Resources Committee in March 2009. A similar bill, the Energy and Water Research Integration Act, passed the House of Representatives in December 2009 and has been referred to Senate committee. Another federal bill, Fiscal 2010 Energy-Water Appropriations (S. 1436 and companion H.R. 3183), which makes appropriations for energy and water development and related agencies for FY2010, recently passed. It appropriates funds to the Army Corps of Engineers Civil Works, Department of the Interior, and Department of Energy for various projects. The bill provides $\$ 33$ billion for energy and water development programs.

\section{Approaches to integrate energy and water policy}

Understanding energy and water data is only the first step in the nexus. Data should ultimately support policy to ensure that the energy and water sectors are being collaboratively regulated and developed. The following policy recommendations are initial steps that can be taken to build the basics of a framework for more integrated energy and water planning:

- Require that applications for new power plants include an analysis of the water and efficiency implications of various types of cooling options applicable to the proposed plant. The analysis should include factors related to local climate and air quality, regional air quality, water availability, including instream flow requirements, fuel type, and plant efficiency.

- Require a clear demonstration of water availability in the siting of new fossil fuelfired or CSP power plants. This analysis should consider average rainfall years as well as water availability during extreme drought events.

- Provide state statutory and regulatory incentives for implementation of power plant cooling technologies that are less water- 
intensive than traditional systems, such as aircooling or hybrid wet-dry cooling.

- Provide state-approved guidance (from the appropriate state agency) to water suppliers and wastewater treatment providers to help quantify energy use and cost savings associated with water conservation.

\section{CONCLUSIONS}

As long as thermoelectric power plants use water cooling technologies, and water and wastewater treatment plants use electricity for processes, it will be important to consider the energy-water nexus in planning and resource management. With population growth, the effects of climate change already impacting the hydrological cycle, and new carbon-pricing policies under consideration, understanding the trade-offs between energy and water becomes vital for resource planning and management.

In conducting this analysis, it became clear that substantially more site-specific data are necessary for a full understanding of the nature of the energywater nexus in Texas. Thus, it is recommended that policy focus on dictating the collection of accurate data on the withdrawal and consumption of cooling and process water at power plants, as well as data on electricity consumption for public water supply and wastewater treatment plants and distribution systems. These data will also be useful in planning for the future, particularly as the impacts of climate change are better understood. Aside from the need for more accurate data to assist with integrated planning in the future, tangible measures can now be taken to assist both sectors with reducing their water and energy consumption.

In the future, water use for electricity generation will depend on several factors, including the fuel mix for new generating capacity, and the type of power plant and cooling system technology that is deployed and where it is located. Likewise, the amount of electricity used to pump, treat, and deliver public water supply and to treat wastewater will depend on choices about water source and treatment technology. These trends and trade-offs still need to be better understood, but it is undeniable that there will be important implications for water and energy policy at the state and local level.
Implementing advanced efficiency is one key to the sustainable use of both energy and water. Improving water efficiency will reduce power demand, and improving energy efficiency will reduce water demand.

Responses to this article can be read online at: http://www.ecologyandsociety.org/voll6/iss 1/art2/responses/

\section{Acknowledgments:}

The authors would like to acknowledge the contributions of Eliot Meyer and Desmond Lawler at the University of Texas at Austin. This work was sponsored by the Energy Foundation and the Texas State Energy Conservation Office.

\section{LITERATURE CITED}

Anderson, J. 2003. The environmental benefits of water recycling and reuse. Water Science and Technology: Water Supply 3(4):1-10.

Asano, T., F. L. Burton, H. L. Leverenz, R. Tsuchihashi, and G. Tchobanoglous. 2007. Water reuse: issues, technologies, and applications. Metcalf \& Eddy, Inc., New York, New York, USA.

California Energy Commission. 2005. California's water-energy relationship. [online] URL: http://ww w.energy.ca.gov/2005publications/CEC-700-2005-011/ CEC-700-2005-011-SF.PDF.

Caputo, A. 2009. Exelon still holding on to Guadalupe water. San Antonio Express-News, 11 July 2009.

Donn, J., M. Mendoza, and J. Pritchard. 2008. Drugs found in drinking water. USA Today, 12 September 2008. [online] URL: http://www.usatod ay.com/news/nation/2008-03-10-drugs-tap-water N. $\underline{\mathrm{htm}}$.

Energy Information Administration. 2008. U.S. data projections, electricity supply and demand, annual energy outlook. [online] URL: http://www.e ia.doe.gov/oiaf/forecasting.html. 
Energy Information Administration. 2009a. Form EIA-906, EIA-920, and EIA-923 databases. [online] URL: http://www.eia.doe.gov/cneaf/electricity/ page/eia906 920.html.

Energy Information Administration. 2009b. Texas electricity profile. [online] URL: http://www. eia.doe.gov/cneaf/electricity/st profiles/texas.html

Environmental Protection Agency. 2008. Envirofacts data warehouse. [online] URL: http://www.epa.gov/ enviro/.

Fthenakis, V., and H. Kim. 2010. Life-cycle uses of water in U.S. electricity generation. Renewable \& Sustainable Energy Reviews 14(7):2039-2048.

Gleick, P. 1994. Water and energy. Annual Review of Energy and the Environment 19:267-299.

Goldstein R., and W. Smith. 2002a. Water \& sustainability (Volume 3): U.S. water consumption for power production - the next half century. Electric Power Research Institute. Palo Alto, California, USA. [online] URL: http://www.circleo fblue.org/waternews/wp-content/uploads/2010/08/EPRIVolume-3.pdf.

Goldstein R., and W. Smith. 2002b. Water \& sustainability (Volume 4): U.S. electricity consumption for water supply \& treatment - the next half century. Electric Power Research Institute. [online] URL: http://www.circleofblue.org/waternews/ wp-content/uploads/2010/08/EPRI-Volume-4.pdf

Gray, K. 2009. Tenaska turns focus to Abilene for its water needs: city says decision will involve public input. Reporter-News, 28 April 2009. [online] URL: http://www.reporternews.com/news /2009/apr/28/tenaska-turns-focus-to-abilene-for-water/

Griffiths-Sattenspiel, B., and W. Wilson. 2009. The carbon footprint of water. River Network, Portland, Oregon, USA.

Intergovernmental Panel on Climate Change (IPCC). 2008. Technical paper on climate change and water. Contribution of Working Group II. IPCC Twenty-eighth session. Budapest. [online] URL: http://www.ipcc.ch/meetings/session28/doc13.pdf
Kasprzyk-Hordern, B., R. Dinsdale, and A. Guwy. 2009. The removal of pharmaceuticals, personal care products, endocrine disruptors and illicit drugs during wastewater treatment and its impact on the quality of receiving waters. Water Research 43(2):363-380.

Keller, A. A., S. Tellinghuisen, C. Lee, D. Larson, B. Dennen, and J. Lee. 2010. Projection of California's future freshwater requirements for power generation. Energy \& Environment 21(2):120.

King C., I. Duncan, and M. Webber. 2008. Water demand projections for power generation in Texas. Texas Water Development Board. [online] URL: http://www.twdb.state.tx.us/wrpi/data/socio/est/Final pwr. pdf.

Klett, M. G., N. J. Kuehn, R. L. Schoff, V. Vaysman, and J. S. White. 2005. Power plant water usage and loss study. National Energy Technology Laboratory. [online] URL: http://www. netl.doe.gov/technologies/coalpower/gasification/pubs/ pdf/WaterReport IGCC Final August2005.pdf.

Koch, H., and S. Vögele. 2009. Dynamic modelling of water demand, water availability and adaptation strategies for power plants to global change. Ecological Economics 68(7):2031-2039.

Masters, G. M. 2004. Renewable and efficient electric power systems. John Wiley \& Sons, Inc., Hoboken, New Jersey, USA.

Metz, B., O. Davidson, H. de Coninck, M. Loos, and L. Meyer, editors. 2005. Carbon dioxide capture and storage. Cambridge University Press, Cambridge, UK.

National Energy Technology Laboratory. 2007. IGCC plants with and without carbon capture and sequestration. [online] URL: http://www.netl.doe.g ov/energy-analyses/pubs/deskreference/B IG 051507. pdf.

National Renewable Energy Laboratory. 2008. Parabolic trough power plant system technology. [online] URL: http://www.nrel.gov/csp/troughnet/p ower plant systems.html.

Poumadere, M., C. Mays, S. Le Mer, and R. Blong. 2005. The 2003 heat wave in France: 
dangerous climate change here and now. Risk Analysis 25(6):1483-1494.

Texas Commission on Environmental Quality. 2008. Site layers. [online] URL: http://www.tceq.st ate.tx.us/gis/sites.html.

Texas Water Development Board. 2007. Waterfor Texas 2007. [online] URL: http://www.twdb.state.tx. us/wrpi/swp/swp.htm.

Texas Water Development Board. 2009. Brackish groundwater desalination one-pager. [online] URL: https://www.twdb.state.tx.us/iwt/desal/facts/ onepagebrack.asp.

Webber, M. 2008. Catch-22: water vs. energy. Scientific American 18(4):34-41.

Webber, M., D. Allen, K. Ferland, C. King, G. McGaughey, S. Goldman, and Y. Kimura. 2008. A clean energy plan for Texas. Texas Commission on Environmental Quality, Austin, Texas, USA.

Wolfe, J., R. Goldstein, J. Maulbetsch, and C. McGowin. 2009. An electric power industry perspective on water use efficiency. Journal of Contemporary Water Research \& Education 143:30-34.

Woods, M. C., P. J. Capicotto, J. L. Haslbeck, N. J. Kuehn, M. Matuszewski, L. L. Pinkerton, M. D. Rutkowski, R. L. Schoff, and V. Vaysman. 2007. Cost and performance baseline for fossil energy plants. Volume 1: bituminous coal and natural gas to electricity. National Energy Technology Laboratory. [online] URL: http://www. netl.doe.gov/energy-analyses/pubs/Bituminous\% 20Baseline Final\%20Report.pdf.

World Coal Institute. 2007. Coal meeting the climate challenge: technology to reduce greenhouse gas emissions. [online] URL: http://www.worldcoal. org/bin/pdf/original pdf file/coal climate change css report(03 06 2009).pdf.

World Economic Forum. 2009. Energy vision update 2009. Thirsty energy: water and energy in the $21^{\text {st }}$ century. [online] URL: http://www2.cera.co m/docs/WEF Fall2008 CERA.pdf. 